\title{
Evaluation of the stability of open bite treatment using a removable appliance with palatal crib combined with high-pull chincup
}

\begin{abstract}
Fernando Pedrin Carvalho Ferreira', Renato Rodrigues de Almeida ${ }^{2}$, Fernando César Torres ${ }^{3}$,
\end{abstract} Renata Rodrigues de Almeida-Pedrin ${ }^{4}$, Marcio Rodrigues de Almeida5, Roberto Santana Filho ${ }^{6}$

Objective: The aim of this prospective study was to cephalometrically analyze the stability of dentoalveolar and skeletal changes produced by a removable appliance with palatal crib associated to high-pull chincup in individuals with anterior open bite treated for 12 months, and compare them to individuals with similar malocclusion and age, not submitted to orthodontic treatment, also followed for the same period. Methods: Nineteen children with a mean age of 9.78 years old treated for 12 months with a removable appliance with palatal crib associated with chincup therapy were evaluated after 15 months (post-treatment period) and compared with a control group of 19 subjects with mean age of 9.10 years with the same malocclusion that was followed-up for the same period. Seventy-six lateral cephalograms were evaluated at $\mathrm{T}_{1}$ (after correction) and $\mathrm{T}_{2}$ (follow-up) and cephalometric variables were analyzed by statistical tests. Results: The results did not show significant skeletal, soft tissue or maxillary dentoalveolar changes. Overall, treatment effects on the experimental group were maintained at $\mathrm{T}_{2}$ evaluation with an increase of $0.56 \mathrm{~mm}$ in overbite. Overjet and maxillary incisors/molars position (vertical and sagittal) remained essentially unchanged during the study period. Only mandibular incisors showed significant changes (labial inclination and protrusion) compared to control group. Conclusions: Thus, it can be concluded that the early open bite treatment with a removable appliance and palatal crib associated with high-pull chincup therapy provided stability of $95 \%$.

Keywords: Open bite. Angle Class I malocclusion. Orthodontics.

Objetivo: avaliar cefalometricamente a estabilidade das alterações dentoesqueléticas e tegumentares, no protocolo de tratamento com o aparelho removível com grade palatina associado à mentoneira, em jovens portadores de mordida aberta anterior tratados por 12 meses, comparando-os com um grupo de jovens portadores de má oclusão semelhante que não foram submetidos ao tratamento ortodôntico. Métodos: avaliou-se um total de 76 telerradiografias em norma lateral de 38 jovens. Dois grupos compuseram a amostra: o Grupo 1 (Controle), composto por 19 jovens (idade média de 9,10 anos) que não receberam qualquer tratamento para a correção de sua má oclusão; e o Grupo 2 (Tratado), composto por 19 jovens (idade média de 9,78 anos) que receberam o protocolo de tratamento durante 12 meses. Verificou-se a estabilidade do tratamento da má oclusão durante aproximadamente 15 meses após a remoção dos aparelhos. Os dados obtidos nas medidas cefalométricas (diferenças das médias das alterações) para os dois grupos foram computados pelo teste $t$ de Student não pareado. Resultados: os resultados mostraram que os componentes esquelético e tegumentar não apresentaram alterações significativas. O overbite, overjete o posicionamento dos dentes superiores mantiveram-se estáveis. Os incisivos inferiores vestibularizaram e protruíram no Grupo Tratado, enquanto o Grupo Controle apresentou maior extrusão desses dentes. Os molares inferiores também extruíram mais significativamente no Grupo controle. Conclusão: pode-se concluir que o protocolo de tratamento da mordida aberta anterior utilizando aparelho removivel com grade palatina associadoà mentoneira mostrou estabilidade de aproximadamente $95 \%$, ressaltando a grande importância desse tratamento na dentição mista. Palavras-chave: Mordida aberta. Má oclusão de Angle Classe I. Ortodontia.

${ }^{1} \mathrm{MSc}$ and $\mathrm{PhD}$ in Orthodontics, FOB/USP. Professor and Coordinator of the Specialization Courses, CORA - Vilhena/RO.

${ }^{2} \mathrm{PhD}$ in Orthodontics, USP. Professor of Orthodontics, FOB/USP.

${ }^{3} \mathrm{MSc}$ and $\mathrm{PhD}$ in Orthodontics, FOB/USP. Associate Professor of the Department of Orthodontics, UNICID.

${ }^{4}$ Post-Doc in Orthodontics and Specialist in Radiology, FOB/USP. Professor of Graduation and Post-Graduation Courses, Sagrado Coração University.

${ }^{5}$ Post-Doc in Orthodontics, FOB/USP.

${ }^{6}$ Specialist in Orthodontics, CORA - Bauru. Professor of Orthodontics, CORA Vilhena/RO.

» The author reports no commercial, proprietary or financial interest in the products or companies described in this article.
How to cite this article: Ferreira FPC, Almeida RR, Torres FC, Almeida-Pedrin RR, Almeida MR, Santana Filho R. Evaluation of the stability of open bite treatment using a removable appliance with palatal crib combined with high-pull chincup. Dental Press J Orthod. 2012 Nov-Dec;17(6):52-60.

Submitted: November 24, 2008 - Revised and accepted: June 26, 2009

" Patients displayed in this article previously approved the use of their facial and intraoral photographs.

Contact address: Fernando Pedrin Carvalho Ferreira

Rua Vereador Leandro dos Santos Martins, 2-20 - Jardim Estoril - Bauru/SP - Brazil CEP: 17017-900 - E-mail: drfernandopedrin@bol.com.br 


\section{INTRODUCTION AND LITERATURE REVIEW}

Stability in orthodontic treatments has always been a challenge for the orthodontists. Correction of vertical dysplasia, such as anterior open bite, has presented high indexes of relapse. Several treatment protocols have been indicated, in different ages, with the same objectives, for reaching an occlusal and facial harmony, ${ }^{1,8,11-13,19,25}$ and, longterm stability.

Systematically evaluating the orthodontic literature, focusing on anterior open bite treatments in the mixed dentition, ${ }^{24}$ only two randomly controlled studies reached the requirements for this selection. The study of Erbay et $\mathrm{al}^{13}$ in which used Frankel functional regulator (FR-4), and other study by Ferreira-Pedrin et $\mathrm{al}^{14}$ in which a removable appliance with a palatal crib combined to a chincup was used. Other systematic reviews ${ }^{8,18}$ evidenced the lack of studies investigating the stability in the mixed dentition, using a treatment protocol and comparing to a matched control group.

Huang et $\mathrm{al}^{19}$ studied stability, after a minimum period of 1 year, in patients with $(n=26)$ and without $(n=7)$ growth treated with palatal crib. In the group without growth, no patients showed relapse; in the group with growth, $17.4 \%$ showed open bite relapse, suggesting that palatal crib treatment provides good results besides stability, probably due to the normalization of tongue posture. Almeida et $\mathrm{al}^{3}$ reported that early treatment promoted anterior open bite correction, and outcome stability.

Another protocol employed, which also verified long-term stability, was performed by LopesGavitto et al. ${ }^{25}$ In the study, the sample comprised of 41 patients who had undergone a conventional treatment with a fixed and extraoral appliance and were compared to a normal occlusion sample. They concluded that more than $35 \%$ of patients experimented relapse of $3 \mathrm{~mm}$ or more.

Using the same sample of Lopez-Gavito et al, ${ }^{25}$ Zuroff, ${ }^{30}$ in 1990, revaluated the stability of the cases using other cephalometric variables for measuring overbite. Overbite was measured by the incisal edges of the upper and lower incisors regarding menton-nasion line. As a result, it was verified that after 10 years, $60 \%$ of patients showed lack of incisal contact.
According to Katsaros and Berg ${ }^{22}$ evaluating patients with anterior open bite (mean of $-1.9 \mathrm{~mm}$ ) treated with edgewise fixed appliance $(n=20)$ and functional appliance $(n=1)$, stability could reach indexes up to $75 \%$. Kim et al, ${ }^{23}$ also evaluated stability after 2 years of anterior open bite correction with fixed appliances, in patients with $(n=29)$ and without $(n=26)$ growth. They observed minimum alterations on overbite and concluded that their results were stable.

Believing that instability of the results obtained after anterior open bite closure would be due to tongue positioning, Justus, ${ }^{21}$ used spurs in order to avoid anterior tongue posture. Treatment protocol showed effectivness on correcting malocclusion and obtaining post-treatment stability.

Huang ${ }^{18}$ performed a literature review focusing on orthodontic and/or surgical treatment of anterior open bite. The evaluated literature suggested that about $80 \%$ of patients who showed anterior open bite, presented after the retention period a positive overbite, regardless of the treatment type (orthodontic or surgical). However, the author highlighted that those results should be cautiously analyzed, since several of these articles had showed methodological failures (small sample and bias during sample selection) and suggested further studies on anterior open bite stability.

Janson et $\mathrm{al}^{20}$ evaluated anterior open bite stability after a mean period of 5 years in patients $(n=21)$ treated with fixed appliance. Results showed significant open bite relapse. The main factor that contributed for the relapse was the deficient vertical development of upper and lower incisors, in the post-treatment period. However, $61.9 \%$ of the cases treated showed a "clinical" stability. Nor the initial magnitude of anterior open bite, neither the total amount of malocclusion correction was correlated to treatment relapse. Freitas et $\mathrm{al}^{15}$ showed longterm stability data of treatment with extractions in the permanent dentition after 8.35 years and concluded that the sample showed clinical stability of $74.2 \%$ of open bite correction.

Emphasizing the need of new researches, $\operatorname{Ren}^{27}$ questioned the systematic review published by Coza et $\mathrm{al}^{8}$ and concluded that the quality of the studies were insufficient for any conclusion based on scientific evidence. 
Due to the lack of studies with appropriate methodology for evaluating treatment stability of anterior open bite in the mixed dentition, it was aimed to cephalometrically analyze the stability of dentoskeletal and profile changes in the treatment with removable appliance with palatal crib associated to high-pull chincup therapy in young patients with anterior open bite who had been treated for 12 months, and to compare them to similar individuals who had not undergone orthodontic treatment.

\section{MATERIAL AND METHODS}

The present study was derived from the research of Ferreira Pedrin in 2006, ${ }^{14}$ which consisted of a prospective randomized study with the treatment of 30 individuals (mean age of 8.33 years) with anterior open bite, who had been compared to a similar control group composed of 30 individuals (mean age of 8.61 years). These authors verified after a 12-month treatment the correction of the malocclusion in 24 individuals who had undergone treatment with a mean overbite closure of $5.01 \mathrm{~mm}$, while control group showed $1.38 \mathrm{~mm}$, allowing the spontaneous correction in only 4 subjects.

It was also aimed in the present study to verify the stability of the effects obtained with the use of the removable appliance with palatal crib combined to high-pull chincup in individuals with mixed dentition.

The sample was composed of 76 lateral cephalograms of 38 young Brazilian subjects of both genders (19 from the treated group and 19 from the control group). Data collected for this study comprised two time periods: $\mathrm{T}_{1}$ (treatment completion) and $\mathrm{T}_{2}$ (15 months post-treatment).

\section{Sample homogeneity}

The criteria for sample selection were based on the following characteristics:

» Young individuals who had undergone treatment of Angle's Class I malocclusion with anterior open bite, for 12 months, with removable appliance with palatal crib associated to high-pull chincup.

» Young individuals with ages varying from 7 to 12 years and presenting the upper permanent first molars in occlusion.
» Caucasian individuals, descending from Italian, Portuguese, and Spanish.

» No dental agenesis or permanent teeth loss.

» This study did not aim to evaluate oral habits (pacifier, thumb suction or oral breathing), or other etiologic factors.

» No young individuals had undergone dental extractions.

\section{Group 1 (control)}

This group comprised 19 young subjects, 17 female and 2 male, with Class I malocclusion with anterior open bite, who had not been submitted to any type of orthodontic treatment, with initial mean age of 9.10 years-old (ranging from 7.31 to 11.51 years). These individuals showed the following initial cephalometric characteristics: $\mathrm{ANB}=4.86^{\circ}$ (ranging from $-0.50^{\circ}$ to $8.50^{\circ}$ ), SN.GoGn $=35.04^{\circ}$ (ranging from $28.20^{\circ}$ to $47.8^{\circ}$ ), and negative overbite of $2.66 \mathrm{~mm}$ (ranging from $-0.10 \mathrm{~mm}$ to $-9.00 \mathrm{~mm}$ ). This group was selected from the files of the Department of Orthodontics of Bauru Dental School - University of São Paulo. The mean interval between the two radiographic examinations used in this group was 15.15 months.

\section{Group 2 (treated)}

Group 2 was composed of 19 young individuals, 13 female and 6 male, who had undergone treatment with removable appliance with palatal crib combined to high-pull chincup, for 12 months, and showed, previously to treatment, a Class I malocclusion with anterior open bite. Mean age at $\mathrm{T}_{1}$ (treatment completion) was 9.78 years (raging from 8.43 to 11.96 years). Patients presented the following cephalometric characteristics at $\mathrm{T}_{1}: \mathrm{ANB}=5.73^{\circ}$ (ranging from $2.00^{\circ}$ to $12.20^{\circ}$ ), SN.GoGn $=35.43^{\circ}$ (ranging from $27.8^{\circ}$ to $46.10^{\circ}$ ) and overbite $=0.94 \mathrm{~mm}$ (ranging from $-3.00 \mathrm{~mm}$ to $3.80 \mathrm{~mm}$ ). From the 30 patients of the previous study sample, ${ }^{14} 11$ could not participate in this present research because 6 moved out of town and 5 patients were using fixed orthodontic appliance. Mean Interval of radiographic exams between $\mathrm{T}_{1}$ and $\mathrm{T}_{2}$ phases used in this group was 15.19 months.

The maturation stage of the cervical vertebrae of both groups was verified according to the classification of Baccetti, Franchi and McNamara. ${ }^{6}$ 
The cephalometric measurements were grouped in sectors regarding to:

1) Maxillary component: SNA and Co-A.

2) Mandibular component: SNB, Ar.GoMe, ArGo, Co-Gn.

3) Maxillomandibular relationship: ANB.

4) Vertical relationship: SN.GoGn, SN.PP, NS.Gn, AFH, PFH, AIFH.

5) Dental component: overbite, overjet, 1.NA, 1-NA, 1-PP, $\underline{6}-\mathrm{FHp}, 6-\mathrm{PP}, 1 . \mathrm{NB}, 1-\mathrm{NB}, \overline{1}-\mathrm{GoMe}$, $\overline{6}$-FHp, 6-GoMe.

6) Soft tissues component: ANL, AML, facial convexity, Ls-P'Sn, and Li-P'Sn.

Aiming to determine the results reliability, 25 radiographs from the two groups studied were randomly selected. All radiographs were again traced and digitized by the same researcher after a 1-month period from the initial tracing, according to the guidelines of Midtgard et al. ${ }^{26}$ The difference between the first and second measurement of each radiograph was determined and the Dalberg's formula ${ }^{10}$ was applied for visualizing the casual error. The systematic error, was obtained by Student's $t$ test, at the significance level of $5 \%(\mathrm{p}<0.05)$.

Statistic analysis was executed employing the non-paired $t$ test, and the results were considered statistically significant for $\mathrm{p}<0.05$. Therefore, the following factors were verified: The similarity degree between Group 1 and Group 2 regarding to the chronological age and evaluation period, the similarity between the cephalometric measurements of the two groups, and, specially, the cephalometric changes occurred in the experimental period.

\section{RESULTS}

\section{Patients age-group}

The patients studied showed initial and final mean age compatibility and were evaluated by a same follow-up period, shown in Tables 1 and 2.

Among the 29 measurements evaluated, it was observed at the significance level of $5 \%$ that no measurement showed systematic error. Regarding casual error, only 3 measurements were greater than $1 \mathrm{~mm}$ for the linear measurements: $\overline{1}-\mathrm{GoMe}(1.29 \mathrm{~mm})$, 6-FHp $(1.27 \mathrm{~mm})$ and $\overline{6}-\mathrm{FHp}(1.26 \mathrm{~mm})$. However, errors from dental measurements are expected according to Baumrind et al. ${ }^{7}$ These values showed that the landmark delimitation or location did not interfere on the obtainment of the cephalometric measurements and did not impair the results, which has been frequently observed on researches, as reported by Baumrind et $\mathrm{al}^{7}$ and Midtgard et al. ${ }^{26}$

Table 3 shows the result of the non-paired $t$ test in the inter-groups comparison, the mean changes for both the control group and the treated group in the final phase of the stability assessment.

Figure 1 shows the difference between groups evidencing the changes due to both craniofacial growth and development and treatment, in the final phase of stability assessment.

In Figure 2, it is possible to observe 3 intraoral anterior photos of a patient during the phases of pre-treatment, 12-month post-treatment, and 15 months after the appliances removal (stability).

In Figure 3, it is observed two intraoral anterior photos of a patient representing control group in the initial and 15-month follow-up phase.

\section{DISCUSSION}

A research published in $2006,{ }^{14}$ performed the comparison of the initial cephalometric measurements between groups, using Student's non-paired $t$ test and the same group of the present study. The purpose of the present paper, however, is to verify stability. The groups showed total similarity in the pre-treatment phase, none of the evaluated variables showed statistical significant difference, reinforcing the reliability between the groups' parity.

Table 1 - Mean age of the individuals in the two groups and the mean time of evaluation.

\begin{tabular}{|cccc|}
\hline Group & $\begin{array}{c}\text { Age at } \mathbf{T}_{\mathbf{1}} \\
\text { (years) }\end{array}$ & $\begin{array}{c}\text { Age at } \mathbf{T}_{\mathbf{2}} \\
\text { (years) }\end{array}$ & $\begin{array}{c}\text { Evaluation time } \\
\text { (months) }\end{array}$ \\
\hline 1 (control) & 9.10 & 10.46 & 15.15 \\
\hline 2(treated) & 9.78 & 10.99 & 15.19 \\
\hline
\end{tabular}

Table 2 - Statistic comparison between the mean age and evaluation periods.

\begin{tabular}{cccccc}
\hline \multicolumn{2}{c}{ Group } & p & SIG. & \\
\hline 1 (control) & $\times$ & 2 (treated) & age $T_{2}$ & 0.06 & n.s. \\
1 (control) & $\times$ & 2 (treated) & evaluation time & 0.98 & n.s. \\
\hline
\end{tabular}

Sig. $=$ significant for $\mathrm{p}<0.05 ;$ n.s. $=$ non significant. 
Table 3 - Difference of the mean changes $(\bar{X}) T_{2}-T_{1}$, standard deviation (SD), p value and statistical significance level.

\begin{tabular}{|c|c|c|c|c|}
\hline Cephalometric measurements & $\begin{array}{l}\text { Control group } \\
\qquad \bar{X} \text { (SD) }\end{array}$ & $\begin{array}{c}\text { Treated group } \\
\bar{X} \text { (SD) }\end{array}$ & $\mathbf{p}$ & Significance \\
\hline \multicolumn{5}{|c|}{ Maxillary } \\
\hline SNA (degrees) & $0.60(2.44)$ & $-0.35(1.65)$ & 0.16 & n.s. \\
\hline Co-A (mm) & $1.46(2.55)$ & $0.60(1.81)$ & 0.23 & n.s. \\
\hline \multicolumn{5}{|c|}{ Mandibular } \\
\hline SNB (degrees) & $0.71(2.35)$ & $0.21(1.33)$ & 0.42 & n.s. \\
\hline $\operatorname{Ar}-\mathrm{Go}(\mathrm{mm})$ & $2.02(2.57)$ & $0.62(2.67)$ & 0.10 & n.s. \\
\hline Ar.GoMe (degrees) & $0.94(3.20)$ & $-0.72(1.79)$ & 0.06 & n.s. \\
\hline Co-Gn (mm) & $2.31(2.73)$ & $1.52(2.32)$ & 0.34 & n.s. \\
\hline \multicolumn{5}{|c|}{ Maxillomandibular } \\
\hline ANB (degrees) & $-0.08(1.40)$ & $-0.54(1.19)$ & 0.29 & n.s. \\
\hline \multicolumn{5}{|c|}{ Vertical } \\
\hline SN.GoGn (degrees) & $0.80(3.12)$ & $-0.40(2.30)$ & 0.65 & n.s. \\
\hline SN.PP (degrees) & $0.02(2.55)$ & $0.36(2.07)$ & 0.65 & n.s. \\
\hline NS.Gn (degrees) & $-0.81(2.01)$ & $-0.34(1.56)$ & 0.42 & n.s. \\
\hline AFA $(\mathrm{mm})$ & $2.05(3.06)$ & $1.94(2.22)$ & 0.89 & n.s. \\
\hline $\operatorname{AFP}(\mathrm{mm})$ & $2.08(2.28)$ & $0.96(2.20)$ & 0.13 & n.s. \\
\hline $\mathrm{AFAl}(\mathrm{mm})$ & $1.74(2.21)$ & $0.38(1.50)$ & 0.03 & sig. ${ }^{\star}$ \\
\hline \multicolumn{5}{|c|}{ Dental } \\
\hline Overbite (mm) & 1.39 (1.77) & $0.56(1.49)$ & 0.10 & n.s. \\
\hline Overjet (mm) & $-0.19(1.45)$ & $-0.77(1.29)$ & 0.20 & n.s. \\
\hline 1.NA (degrees) & $1.71(4.88)$ & $2.35(4.04)$ & 0.66 & n.s. \\
\hline 1-NA (mm) & $0.15(1.55)$ & $0.73(1.31)$ & 0.22 & n.s. \\
\hline 1-PP $(\mathrm{mm})$ & $0.78(1.58)$ & $0.77(1.24)$ & 0.98 & n.s. \\
\hline$\underline{6}-\mathrm{FHp}(\mathrm{mm})$ & $1.81(3.94)$ & $1.92(2.44)$ & 0.91 & n.s. \\
\hline$\underline{6}-P P(\mathrm{~mm})$ & $0.96(1.51)$ & $1.10(1.34)$ & 0.77 & n.s. \\
\hline 1.NB (degrees) & $-1.92(4.57)$ & $3.23(4.64)$ & $<0.001$ & $\operatorname{sig}^{\star \star}$ \\
\hline $1-\mathrm{NB}(\mathrm{mm})$ & $0.18(1.32)$ & $1.00(1.02)$ & 0.04 & sig. ${ }^{\star}$ \\
\hline 1-GoMe (mm) & $2.20(1.66)$ & $0.72(1.12)$ & $<0.001$ & $\operatorname{sig}^{\star \star}$ \\
\hline 1-FHp (mm) & $0.84(3.81)$ & $2.20(2.05)$ & 0.72 & n.s. \\
\hline 1-GoMe (mm) & $1.48(1.55)$ & $0.14(0.77)$ & $<0.001$ & sig. ${ }^{\star \star}$ \\
\hline \multicolumn{5}{|c|}{ Soft tissue } \\
\hline Nasolabial angle (degrees) & $-2.38(10.10)$ & $2.20(8.62)$ & 0.14 & n.s. \\
\hline Mentolabial angle(degrees) & $0.42(0.93)$ & $0.64(1.17)$ & 0.51 & n.s. \\
\hline GI.Sn.P' (degrees) & $-1.05(3.04)$ & $-1.38(2.48)$ & 0.71 & n.s. \\
\hline UL-P'Sn (mm) & $-0.26(1.52)$ & $-0.44(1.74)$ & 0.74 & n.s. \\
\hline LL-P'Sn (mm) & $0.02(1.40)$ & $0.34(1.18)$ & 0.45 & n.s. \\
\hline
\end{tabular}

n.s. $=$ non significant. Sig. ${ }^{\star}=$ significant $(p \leq 0.05)$ Sig. $.^{\star \star}=$ significant $(p \leq 0.01)$.

It was observed that there was a greater number of young females than males. This fact did not impair the comparison of changes between groups, because an appropriate proportion of gender between treated and control groups could also be observed.
In this prospective study, an experimental group that underwent treatment with a removable appliance with palatal crib combined with a high-pull chincup, during 12 months, was compared to a group without treatment. From that point, the results re- 


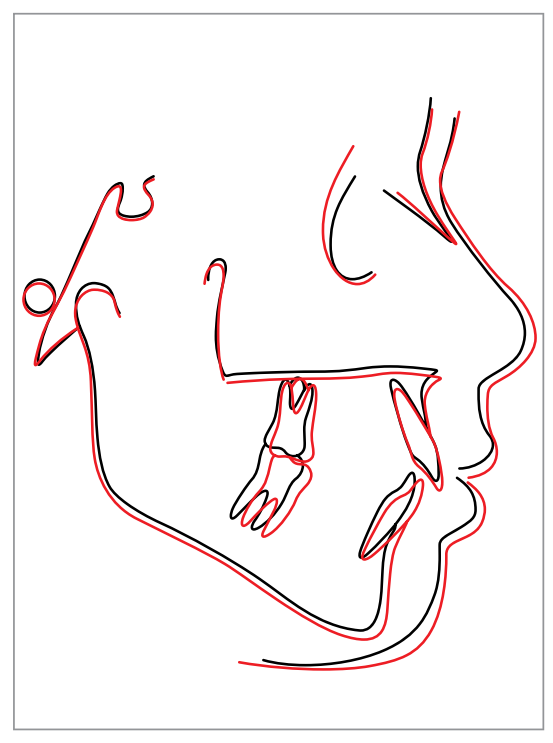

Figure 1 - Total superimposition (S-N) of the means of the control group (white) and the treated group (red) in the final phase of the stability assessment.
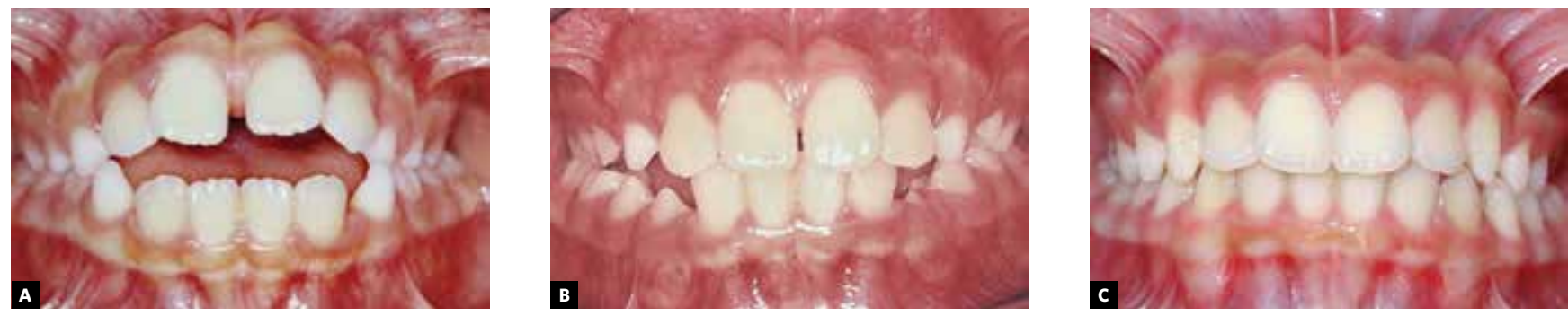

Figure 2 - Intraoral photos of treated group: A) Initial $\left.\left(T_{0}\right) ; \mathbf{B}\right)$ after 12 months $\left.\left(T_{1}\right) ; \mathbf{C}\right) 15$ months after appliances removal $\left(T_{2}\right)$.

Figure 3 - Intraoral photos of control group: A) initial $\left.\left(T_{1}\right) ; \mathbf{B}\right) 15$ months of follow-up $\left(T_{2}\right)$.
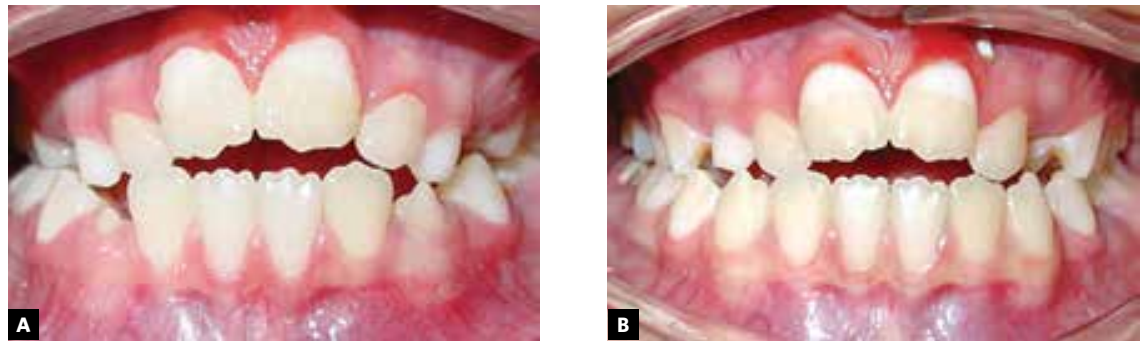

garding stability during a period of about 15 months was assessed. The obtained values were compared to a control group with similar characteristics.

Several studies describe anterior open bite treatment, however, the literature lacks for studies evaluating outcome stability. Others ${ }^{15,20,23}$ have evaluated stability, however, using distinct protocols in patients with more advanced ages.

No study with proper methodology has evaluated this issue. .,18,24,27 $^{2}$ 


\section{Changes comparisons between groups}

In the inter-groups comparison, it was possible to identify small dentoskeletal and soft tissue changes, showing that the early treatment of anterior open bite seemed to be very stable.

From all skeletal measurements, only AIFH was statistically different between groups, which was influenced by the dental factor. This occurred due to a greater extrusion of lower molars in the control group $(2.20 \mathrm{~mm})$ compared to treated group $(0.72 \mathrm{~mm})$.

Aiming to verify the stability of the effects obtained on treatment regarding anterior overbite, the methodology employed in this research assessed the distance between the incisal edges of the upper and lower incisors perpendicular to the occlusal plane. ${ }^{14,20}$

A previous study published by Ferreira-Pedrin et al, in 2006, ${ }^{14}$ verified a mean decrease of overbite of 5.01 $\mathrm{mm}$ for the group treated with removable appliance with palatal crib combined with high-pull chincup, while control group showed $1.38 \mathrm{~mm}$. Due to the initial anterior open bite of $-3.95 \mathrm{~mm}$ in the treated group, overbite correction was possible to be achieved in 24 out of 30 patients. In the control group, anterior open bite was initially $-4.01 \mathrm{~mm}$, which was sufficient for the overbite correction in only 4 out of 30 individuals.

When evaluating the stability of both control and treated groups, these presented initial mean values of $-2.66 \mathrm{~mm}$ and $0.94 \mathrm{~mm}$, respectively, which were statistically different. This was already expected since group 2 (treated) had been treated for 12 months, while group 1 (control) had not undergone any treatment, maintaining the negative overbite.

After a mean radiographic follow-up period of 15 months, it was verified that the control group showed a mean increase of overbite of $1.39 \mathrm{~mm}$. Out of 19 young individuals of the control group, 7 showed a positive overbite, 5 had an overbite reduction worsening the malocclusion, and 7 increased the values of this variable. However, these values were not sufficient for correction, maintaining the anterior open bite.

In the treated group, a mean increase of overbite of $0.56 \mathrm{~mm}$ was verified, resulting in an overbite improvement in 12 of the 19 young individuals evaluated. This value was reached due to the influence of the intrinsic growth of the treated patients besides the results obtained from the treatment protocol used. Seven of the 19 individuals of the treated group showed overbite reduction, and only one patient showed anterior open bite relapse, with initial overbite of $0.7 \mathrm{~mm}$ and final of $-0.7 \mathrm{~mm}$. Another young individual with initial overbite of -3 mm presented a spontaneous improvement of overbite and finished with $-1 \mathrm{~mm}$, without malocclusion correction.

The differences between the two groups were not statistically significant. However, it was estimated that the lowest increase in the treated group occurred due to the loss of the mechanism that instructed the tongue posture regarding the interference and contact between teeth, which could have generated new interferences, ${ }^{16}$ while the control group only suffered the influence of growth and development, with aging.

When verifying the mean changes the lower incisors variables showed statistical significant differences between groups. In the control group, the means of the incisor changes represented retroclination $\left(\overline{\mathrm{l}} \cdot \mathrm{NB}=-1.92^{\circ}\right)$, protrusion $(\overline{\mathrm{l}}-\mathrm{NB}=0.18 \mathrm{~mm})$ and extrusion $(\overline{\mathrm{l}}-\mathrm{GoMe}=2.20 \mathrm{~mm})$. In the treated group, the mean change represented proclination $\left(1 . \mathrm{NB}=3.23^{\circ}\right)$, protrusion $(\overline{\mathrm{l}}-\mathrm{GoMe}=1.00 \mathrm{~mm})$, and extrusion ( $\overline{\mathrm{l}}-\mathrm{GoMe}=0.72 \mathrm{~mm})$.

The probable factor responsible for the proclination of the lower incisors in the treated group is tongue action on the incisors due to the removal of the palatal crib. Ferreira-Pedrin et $\mathrm{al}^{14}$ and Torres et $\mathrm{al}^{29}$ evidenced the retroclination of these same teeth, due to the difficulty of tongue contact promoted by the palatal crib, therefore making the lower lip act more strongly on these teeth. This action promoted a statistical significant retroclination of these teeth during the use of the appliance, therefore, treatment provided an improvement in lip sealing. On the other hand, in average, the control group showed lingual tipping probably because they would still present some oral habit, since no treatment had been employed at that moment.

Corroborating with these results, other authors ${ }^{20}$ also observed proclination and protrusion of lower incisors in the post-treatment period.

Regarding vertical positioning of lower incisors, both groups showed an increase of the $\overline{\mathrm{l}}$-GoMe measurement, denoting an extrusion of these teeth, and showing a statistically significant difference between them. Dental extrusion probably occurred due to the lack of contact with the palatal surface of the upper incisors, which occurred more in the control group. 
Table 4 - Studies on anterior open bite stability.

\begin{tabular}{|c|c|c|c|c|}
\hline Authors & Appliance used & Sample & OB Control group & \% Stability \\
\hline $\begin{array}{l}\text { Huang, Justus, } \\
\text { Kennedy }^{19} \text { (1990) }\end{array}$ & Palatal crib & $\begin{array}{l}\text { Group with growth } \\
\text { Group with no growth }\end{array}$ & No & $\begin{array}{l}82.6 \% \\
100 \%\end{array}$ \\
\hline Lopez-Gavito et al ${ }^{25}$ (1985) & Fixed appliances with elastics & Adults & No & $65 \%$ \\
\hline Zuroff ${ }^{30}(1990)$ & Fixed appliances with elastics & Adults & No & $40 \%$ \\
\hline Katsaros, Berg'22 (1993) & Fixed and functional appliances & Adults & No & $75 \%$ \\
\hline Kim et $\mathrm{al}^{23}(2000)$ & MEAW fixed appliance & $\begin{array}{l}\text { Group with growth } \\
\text { (mean age } 18 \text { yrs) } \\
\text { Group with no growth } \\
\text { (mean age } 18 \text { yrs) }\end{array}$ & No & $\begin{array}{l}97 \% \\
95 \%\end{array}$ \\
\hline Janson et $\mathrm{al}^{20}(2006)$ & Non-extraction fixed appliance & Young adults & No & $61.9 \%$ \\
\hline Freitas et al15 (2004) & Extraction fixed appliance & Young adults & No & $72.4 \%$ \\
\hline Crepaldi $^{9}$ (2008) & Occlusal adjustment & Young adults & No & $66.7 \%$ \\
\hline Ferreira-Pedrin ${ }^{14}(2006)$ & $\begin{array}{c}\text { Removable crib appliance with } \\
\text { chincup }\end{array}$ & Mixed dentition & Yes & $95 \%$ \\
\hline
\end{tabular}

When verifying stability, Freitas et $\mathrm{al}^{15}$ also observed significant extrusion of incisors.

In relation to vertical displacement, lower molars showed an extrusion of $1.4 \mathrm{~mm}$ in the control group and $0.14 \mathrm{~mm}$ in the treated group, with statistically significant difference. This could be explained by the occlusal improvement and probable muscular balance in the treated group, while in the control group this fact did not occur (occlusal balance), contributing to the stability of anterior open bite correction.

Some studies that assessed stability ${ }^{23}$ found molar extrusion in the post-treatment phase, which could have contributed for the anterior open bite relapse.

The effects promoted by 12 months of treatment with the use of removable appliance with palatal crib combined with high-pull chincup evidenced about $95 \%$ of stability. Other studies ${ }^{9,15,19,22,23,25,30}$ which verified treatment stability of anterior open bite obtained distinct values and did not make a comparison with a matched control group regarding malocclusion.

Table 4 lists the main studies that evaluated treatment stability of anterior open bite, exposing the percentages of maintenance results.

\section{CLINICAL CONSIDERATIONS}

Due to the results obtained in this prospective research and evaluating the stability of the clinical effects after using removable appliance with palatal crib combined with high-pull chincup in the treatment of the anterior open bite, it was demonstrated that during a follow-up period of 15 months after appliance removal it was possible to maintain the good occlusal relationship obtained by the treatment, satisfying the functional (occlusal), esthetical and social necessities of the treated young individuals.

The effects of craniofacial growth and development on patients with anterior open bite who did not undergo treatment (control group) were maintained constant, perpetuating the malocclusion, verifying the need of intervention in 12 of the 19 patients. In private clinic routine, aiming to treat anterior open bite, appliances have been used until reaching a positive overbite. It is worth using retainers after early correction of this malocclusion, besides the interaction with other specialties (otorhinolaryngology, speech therapy) and periodical follow-up, which would probably provide a better stability.

\section{CONCLUSIONS}

The results of this study indicated that the anterior open bite treatment in the mixed dentition, using removable appliance with palatal crib combined with high-pull chincup promoted $95 \%$ of dental and skeletal stability because only lower incisors presented significant changes when compared to the control group. 


\section{REFERENCES}

1. Alexander CD. Open bite, dental alveolar protrusion, Class I malocclusion: A successful treatment result. Am J Orthod Dentofacial Orthop. 1999;116(5):494-500.

2. Almeida RR, Almeida-Pedrin RR, Almeida MR, Ferreira FPC, Pinzan A, Insabralde CMB. Displasias verticais: mordida aberta anterior - tratamento e estabilidade. Rev Dental Press Ortod Ortop Facial. 2003;8(4):91-119.

3. Almeida RR, Henriques JFC, Almeida MR, Vasconcelos MHF. Early treatment of anterior open bite - prevention of orthognatic surgery. In: Davidovitch Z, Mah J, editors. Biological mechanisms of tooth eruption, resorption and replacement by implants. Boston: Harvard Society for the Advancement of Orthodontics; 1998. p. 585-8.

4. Almeida RR, Ursi WJS. Anterior open bite. Etiology and treatment. Oral Health. 1990:80:27-31.

5. Almeida RR, Garib DG, Henriques JFC, Almeida MR, Almeida RR. Ortodontia preventiva e interceptadora: mito ou realidade. Rev Dental Press Ortod Ortop Maxilar. 1999:(6):87-108.

6. Baccetti T, Franchi L, McNamara JA Jr. An improved version of the cervical vertebral maturation (CVM) method for the assessment of mandibular growth Angle Orthod. 2002;72(4):316-23.

7. Baumrind S, Miller D, Molthen R. The reliability of head film measurements: 3 . Tracing superimposition. Am J Orthod. 1976;70(6):617-44.

8. Cozza P, Baccetti T, Franchi L, Mucedero M, Polimeni A. Sucking habits and facial hyperdivergency as risk factors for anterior open bite in the mixed dentition. Am J Orthod Dentofacial Orthop. 2005;128(4):517-9.

9. Crepaldi MV. Estabilidade do tratamento da mordida aberta com ajuste oclusal [dissertação]. Bauru (SP): Universidade de São Paulo; 2008.

10. Dahlberg G. Statistical methods for medical and biological students. New York: Interscience; 1940.

11. Defraia E, Marinelli A, Baroni G, Franchi L, Baccetti T. Early orthodontic treatment of skeletal open-bite malocclusion with the open-bite bionator: A cephalometric study. Am J Orthod Dentofacial Orthop. 2007;132(5):595-8.

12. English JD. Early treatment of skeletal open bite malocclusions. Am J Orthod Dentofacial Orthop. 2002;121:563-5.

13. Erbay $E$, Uğur $T$, Ulgen $M$. The effects of Frankel function regulator (FR-4) therapy on the treatment of Angle Class I skeletal anterior open bite malocclusion. Am J Orthod Dentofacial Orthop. 1995;108(1):9-21.

14. Pedrin F, Almeida MR, Almeida RR, Almeida-Pedrin RR, Torres F. A prospective study of the treatment effects of a removable appliance with palatal crib combined with high-pull chincup therapy in anterior open-bite patients. Am J Orthod Dentofacial Orthop. 2006;129(3):418-23.

15. Freitas MR, Beltrão RT, Janson G, Henriques JF, Cançado RH. Long-term stability of anterior open bite extraction treatment in the permanent dentition. Am J Orthod Dentofacial Orthop. 2004:125(1):78-87.
16. Haryett RD, Hansen FC, Davidson PO. Chronic thumb-sucking. A second report on treatment and its psychological effects. Am J Orthod. 1970:57(2):164-78.

17. Houston WJB. The analysis of errors in orthodontic measurements. Am J Orthod. 1983;83(5):382-90.

18. Huang GJ. Long-term stability of anterior open-bite therapy: a review. Semin Orthod. 2002;8(3):162-72

19. Huang GJ, Justus R, Kennedy DB, Kokich VG. Stability of anterior open bite treated with crib therapy. Angle Orthod. 1990;60(1):17-24; discussion 25-6.

20. Janson G, Valarelli FP, Beltrão RT, de Freitas MR, Henriques JF. Stability of anterior open-bite extraction and nonextraction treatment in the permanent dentition. Am J Orthod Dentofacial Orthop. 2006:129(6):768-74.

21. Justus R. Correction of anterior open bite with spurs: long-term stability. World J Orthod. 2001;2(3):219-31

22. Katsaros C, Berg R. Anterior open bite malocclusion: a follow-up study of orthodontic treatment effects. Eur J Orthod. 1993;15(4):273-80.

23. Kim YH, Han UK, Lim DD, Serraon ML. Stability of anterior openbite correction with multiloop edgewise archwire therapy: a cephalometric follow-up study. Am J Orthod Dentofacial Orthop. 2000;118(1):43-54

24. Lentini-Oliveira D, Carvalho FR, Qingsong Y, Junjie L, Saconato H, Machado MA et al. Orthodontic and orthopaedic treatment for anterior open bite in children (Cochrane Review). Cochrane Database Syst Rev. 2007:18(2):CD005515.

25. Lopez-Gavito G, Wallen TR, Little RM, Joondeph R. Anterior open-bite malocclusion: a longitudinal 10 years post retention evaluation of orthodontically treated patients. Am J Orthod. 1985:87:175-86.

26. Midtgård J, Björk G, Linder-Aronson S. Reproducibility of cephalometric landmarks and errors of measurements of cephalometric cranial distances. Angle Orthod. 1974;44(1):56-61.

27. Ren Y. Is early treatment of skeletal open-bite malocclusion effective? EvidenceBased Dent. 2006;7:81-2.

28. Shapiro P. Stability of open bite treatment. Am J Orthod Dentofacial Orthop. 2002;121(6):566-8

29. Torres FC, Almeida RR, Almeida MR, Almeida-Pedrin RR, Pedrin F, Henriques JFC. Anterior open bite treated with a palatal crib and high-pull chin cup therapy. A prospective randomized study. Eur J Orthod. 2006;28(6):610-7.

30. Zuroff JP. Orthodontic treatment of anterior open-bite malocclusion: stability ten years post-retention [thesis]. Seattle (WA): University of Washington; 1990. 